\title{
Introduction: Company Tax Integration in the European Union - A Necessary Step to Neutralise 'Excessive' Behaviour within the
} EU?

\author{
Arnaud de Graaf \& Klaus Heine*
}

This special issue of the Erasmus Lam Reviem is the result of an interdisciplinary workshop on 'Company Tax Integration in the European Union - a Necessary Step to Neutralise "Excessive" Behaviour within the EU?', held at the Erasmus School of Law in June 2013 and organized by the Foundation European Fiscal Studies in co-operation with Erasmus Lam Reviem. ${ }^{1}$ A topic currently attracting considerable public attention, not least because of the Base Erosion and Profit Shifting (BEPS) project of the OECD instigated by the G20.

During the past decades there has been intensive tax competition between EU Member States for attracting capital triggered inter alia by the four freedoms as laid down in the European treaties. ${ }^{2}$ Even though competition is widely seen as beneficial to society, ${ }^{3}$ in case of inter-jurisdictional tax competition this may not always be the case. ${ }^{4}$ The possible negative effects of inter-jurisdictional tax competition and aggressive tax planning by multinational companies on state's tax revenue may lead to a shift of the tax burden onto less mobile activities and onto consumption in order to keep a state's public finances stable. In the end a jurisdiction's tax system may become distorted (inefficient) and distribution unfair. In order to neutralize the negative effects of harmful tax competition and aggressive tax planning, one might be of the opinion that integrating company taxes within the EU would be the only way forward.

There are good arguments for and against company tax integration within the EU. These arguments have already been discussed intensively from the start of the EU-project. ${ }^{5}$ Irrespective of whether one belongs to the supporters or opponents of company tax integration,

* $\quad$ Erasmus School of Law, Erasmus University Rotterdam. Erasmus School of Law, Tax Law Department, Erasmus University Rotterdam.

1. A report on the conference written by $M$. Schippers has been published in EC Tax Review 2013/5, 258-263.

2. W. Kerber, 'Interjurisdictional Competition Within the European Union', 23 Fordham International Law Journal, at 217-249 (1999).

3. For example, R.S. Pindyck and D.L. Rubinfeld, Microeconomics, 4th edn. (1997), at 579.

4. H.-W. Sinn, 'The Selection Principle and Market Failure in Systems Competition', 66 Journal of Public Economics , at 247-274 (1997).

5. J. Mintz, 'Corporate Tax Harmonization in Europe: It's All About Compliance', 11 International Tax and Public Finance, at 221-234 (2004). current practice makes clear that some kind of 'order' is needed to set the rules of the game for inter-jurisdictional tax competition and aggressive tax planning by multinational companies. But there are very practical legal problems, too. The sheer number of Member States as well as the unanimity requirement and proEuropean stance of the EU institutions prevent a step towards further company tax integration under the EU umbrella.

If integration is reached under the EU umbrella, another question comes up as to the sharing of the tax revenue. The allocation key proposed by the European Commission under the proposed CCCTB-directive might be positive for the larger Member States, like France and Germany, but disadvantageous to the smaller ones. Besides, the issue might arise whether the revenue should go into the coffers of the European Union instead of the ones of the Member States. This question is very topical in the light of the recent sovereign debt crisis of Member States, when Member States agreed to implement 'debt brakes' into their constitutions. ${ }^{6}$

This special issue comprises four topical contributions.

1. The contribution by Baskaran and Lopes da Fonseca (both from the University of Göttingen, Germany) is concerned with a survey of the empirical literature on inter-jurisdictional tax competition. Thereby they discuss in depth whether tax competition leads to a race to the bottom with regard to tax revenue, making tax integration inevitable. However, the authors can show empirically that tax revenue in the EU does not decrease as strong as one might suspect. Therefore, they suggest that a system of intergovernmental transfers could be more appropriate for sharing revenue between Member States than preventing tax competition at all. As a consequence it might be possible to prevent politicians from exploiting citizens and firms (tax competition) and having at the same time sound revenues for the Member States (intergovernmental transfers).

2. Vrijburg (Erasmus University Rotterdam) devotes his contribution to the question of whether, from the

6. K. Mause and F. Groeteke, "New Constitutional "Debt Brakes" for Euroland? A Question of Institutional Complementarity', 23 Constitutional Political Economy, at 279-301 (2012). 
perspective of an economist, supranational cooperation is needed to stop 'excessive company taxation practices' within the EU (encompassing inter-jurisdictional tax competition and tax-planning activities by multinational companies). First, he discusses the main conclusions in the economic literature on this question. Thereafter, he develops a conceptual framework to structure the debate on the question whether excessive company taxation practices harm welfare. Thereby he asks himself the question whether government action should be undertaken at all to remove excessive company taxation. The theoretical perspective allows Vrijburg to pinpoint the fundamental problems that company taxation raises for economists. He draws a complicated picture in which the positive or negative welfare effect of company taxation strongly depends on the assumptions of the presumed model. This leads Vrijburg to subscribe to the wide held opinion in economics that corporate taxation should be designed as a subcategory of individual capital income taxation. That means he recommends policy makers to rely as much as possible on individual income taxation and to avoid company taxation to the extent possible, in order to prevent unforeseen negative effects of company taxation.

3. In his contribution, De Wilde (Erasmus University Rotterdam) asks himself the question whether the European Commission's proposal for a Council Directive on a Common Consolidated Corporate Tax Base (CCCTB) leading to an integration of the company taxes of the EU Member States is a solution to tax competition within the EU. After having analysed the EC's proposal, he concludes that this proposal also provides incentives for multinationals to pursue artificial tax base-shifting practices within the EU, potentially invigorating the risk of undue governmental tax competition responses (referring to it as a 'race to the bottom 2.0'). Therefore, he suggests assessing alternatives to the sharing mechanism as proposed by the EC. As an alternative sharing mechanism, he favours using a quantitative 'factor presence test' to attribute the tax base to EU Member States.

4. Finally, Sting (Erasmus University Rotterdam) discusses the main legal obstacles the EU treaties pose for integrating company taxes within the EU. The main problem she identified is the unanimity requirement. To overcome this problem, she considers treaty change, enhanced cooperation, soft law approaches and also indirect harmonisation through the new system of economic governance. Eventually, a possible non-EU option is considered. However, she recommends making use of the current EU law framework, such as soft law approaches and the system of the new economic governance to achieve a more subtle and less intrusive company tax integration, or instead a treaty change that would legitimately enhance and further economic integration in the field of taxation. 